\title{
An Exploratory Analysis on Entrepreneurial Culture and Financial Education Between Students of the Veracruzana University, Veracruz Region
}

\author{
Prof. Dr. Ignacio Ortiz Betancourt \\ Universidad Veracruzana, Mexico
}

\begin{abstract}
Entrepreneurial culture and financial education have become two of the most relevant issues on the international agenda, since they are considered as elements in favor of the efficient use of financial resources, as well as they are important for the identification of opportunities which favor the development of self-employment projects, contributing to local economic growth. Nevertheless, Mexican financial authorities note that there is an environment with gaps and deficiencies in terms of financial education, which is more evident among the rural population and sectors of lower education and socioeconomic level, causing inefficient use of resources and a poor culture of financial management, which undoubtedly compromises the stability of most Mexican families. In addition, this lack of financial education has a negative impact on the development of entrepreneurial projects, generating greater economic and social problems, taking into account that entrepreneurship is a mechanism that contributes to the creation of jobs and encourages economic growth. Based on these premises, this study aims to identify the level of entrepreneurial culture and financial education among Universidad Veracruzana students, through a descriptive and exploratory analysis; results shown a high level of entrepreneurial culture and a medium level of financial education but a weak positive correlation among them.
\end{abstract}

Keywords: entrepreneurial culture; financial education; Latin America university context.

\section{Introduction}

According to the OECD (2010), entrepreneurs are participants of particular relevance in innovation; as they help turn ideas into practical applications. In the United States, in 2007, companies under the age of five accounted for almost threequarters of new net jobs. Successful business creation often comes with practice; hence the importance of experimentation, the entry and exit of the market. However, only a small part of the population receives education for the creation of companies. Education and training policies should help foster an entrepreneurial culture to instill the skills and attitudes necessary for a creative drive.

Among main topics for policy makers, financial education takes an important spot due to its impact among small business and entrepreneurs. This is why international organizations such as OECD, World Bank and International Monetary Fund have developed strategies to increase the levels of financial skills among developed countries, emerging economies and less developed regions. Then, entrepreneurial culture and financial education stand out as two fundamental issues on the international agenda, since elements are considered in favor of the efficient use of financial resources, as well as the identification of opportunities for the development of self-employment projects, contributing to local economic growth.

According to the National Commission for the Protection and Defense of Financial Services Users (CONDUSEF, 2012), financial education can be defined as the set of actions that imply learning to manage money better, being foresighted, consuming in a rational way, and learn to invest, know how to take care of your assets and use financial products and services with responsibility.

Similarly, Smyth (2011) points out that financial education is the process by which consumers improve the understanding of financial products and acquire a greater understanding of financial risks and market opportunities, by making economic decisions with information. In addition, he points out that an important part of our decisions is associated with financial behavior, which directly impacts his personal and family environment, from the search for funding for studies to planning 
for retirement. Thus, having an adequate financial education will favor an intelligent selection of financial products, based on well-informed decisions.

The benefits of having an adequate financial education also extend to the national economic level, since, as BBVA (2015) points out, greater economic and financial education helps explain the level of financial development in the country, and which ultimately leads to lower inequality. In this way, having policies in charge of promoting these issues would contribute to reducing inequality by allowing large groups of the population of a country to access the financial markets to monetize their savings. This can also favor an improvement and development of the domestic financial market and consequently contribute to economic growth.

However, the picture of financial education in Mexico is unfavorable, since as mentioned by BANAMEX \& UNAM (2008) in the results of the First Survey on Financial Culture in Mexico, there is, in the majority of the population, a medium- or longterm vision in matters related to finances. In addition, this work identified an incipient "control and expenditure planning" culture. This is because, overall, about one in five households had a record of expenditures or planned income, debt and household savings.

In this sense, it is observed that in Mexico there is an environment with gaps and gaps in terms of financial culture, both training and information, which becomes more evident among the rural population and sectors of lower education and socioeconomic level, causing serious consequences, such as the absence of planning in the control of expenses, income and debt, lack of savings and a culture of foresight, which undoubtedly compromises the stability of most Mexican families.

In addition to this, this lack of financial education has repercussions in the area of business, and especially among the projects of micro, small and medium enterprises (MSMEs) and entrepreneurs, which, according to Carton, Hofer \& Meeks (1998) are those people with the ability to identify market opportunities to create companies and thus generate value. Recently, the World Bank (2015a) stated that, until very recently, the motivation to become an entrepreneur was to earn a lot of money to have a relaxed life and full of amenities. But lately a new generation of entrepreneurs has emerged who, in addition to modern and profitable ideas, incorporate social and environmental benefits into their business plans.

This is evident since, as Lederman et al (2014) mention that there is a large gap between the capacity to access financing between large companies and the rest, with larger ones being widely favored. This difficulty faced by MSMEs to raise capital also implies greater demands on their use, which undoubtedly requires an adequate level of financial education. In addition, Lederman et al ( 2014) point out that it is possible that this barrier of access to financing that new companies experience is negatively affecting the entrepreneurial potential of Latin America and the Caribbean.

Considering the negative effect that credit scarcity produces on entrepreneurship, Cai (2015) states that during last years some financial institutions in African countries have developed strategies to reduce credit rates in order to promote entrepreneurial projects; for example, the Chase Bank of Kenya managed to reduce the interest rate paid by women's companies and works to exponentially increase the size of the loan portfolio for these types of enterprises. All these efforts allow more companies to invest in their businesses with reasonable costs. This creates new jobs and contributes to local economic growth.

In Latin America, the Mexican Federal Government created in 2014 the National Fund for Entrepreneurs which aims to stimulate national, regional and sectoral economic growth, through the promotion of productivity and innovation in micro, small and medium enterprises located in strategic sectors, which promotes a systematic strengthening of entrepreneurship development throughout the national territory, as well as the consolidation of an innovative, dynamic and competitive economy.

Also, Marin (2014) stresses the importance of entrepreneurs have the ability to evidence their knowledge in financial matters, because in this way they can overcome the challenges of the market. Similarly, Di Costanzo (2013) argues that a company that begins operations without basic financial education has a high chance of failure, while those that incorporate good financial practices increase their chances of remaining in the market. Thus, it can be seen that financial education has a great influence on the success of entrepreneurial projects.

Nevertheless, Blasco (2012) mentions that some of the main obstacles for enhancing entrepreneurship are the lack of financial resources or the restrictions to access to credit markets, public policies and a low entrepreneurial skills. 
Once the importance of the topics of financial education and entrepreneurship in the national and international agencies has been identified, the need arises to identify one of the main spaces where strategies can be designed and implemented in favor of these topics: the University. This, as mentioned by Neck (2014), education is an essential factor to start a business, and therefore the university gives the student the space where he can practice the venture, and at the same time can learn how to deal and manage the uncertainty of the market, which is part of the world of entrepreneurship.

Thus, universities have a fundamental role in the process of training competent individuals to face the demands of an increasingly competitive labor market, in which they will have to make use of financial tools and entrepreneurial skills. However, Lopez (2010) emphasizes the fact that the level of schooling is not directly related to the degree of financial education of individuals.

Based on the above, there is interest in identifying the level of financial education and how widespread is the entrepreneurial culture among university students in our country. However, given the large potential population to be addressed during this work, we intend to limit our scope to the context of Veracruz (southern Mexican federal entity), in which, the Veracruzana University represents the main house of studies given its presence and coverage in twenty-eight municipalities distributed in five regions: Xalapa, Veracruz, Orizaba-Córdoba, Poza Rica-Tuxpan and Coatzacoalcos-Minatitlán. Within these, the second largest number of students is the Veracruz region, which is limited in our immediate area of study.

Given these premises, the following research question is proposed that will lead to the development of this project: what is the level of financial education and entrepreneurial culture among the students of the Veracruz University, Veracruz region? Next, we present a series of arguments that validate the relevance of this work.

\section{Justification}

The close relationship that exists between the level of financial education and the level of success of entrepreneurial projects is very important since they affect the pattern of economic growth in emerging economies. It is for this reason that the Inter-American Development Bank (IDB, 2014) has emphasized among senior officials of ministries and agencies of Science, Technology and Innovation of Latin America and the Caribbean the need to discuss public policies that promote entrepreneurship. In addition, this institution continues to promote the dissemination of financial education programs, since these have a fundamental impact on the well-being of citizens (IDB, 2015). Similarly, the World Bank (2013) notes that the relationship between productivity and economic growth has meant that governments and multilateral agencies in recent years have given more attention and support to entrepreneurship: that is, the ability to turn ideas into products and services. For example, the Mexican government has made legal reforms to encourage entrepreneurship and recently created the National Institute of Entrepreneurs (INADEM) to promote the culture and productivity of entrepreneurs and ease credit access through programs such as "Young Credit" which is designed for different profiles of young entrepreneurs with solid business projects (CONDUSEF, 2015).

As pointed recently, these efforts lie on the widely accepted premise that closely links business to economic growth and productivity (Lupiáñez, Priede and López-Cózar, 2014). In this sense, they emphasize that the business aggregate and the creation of new units represent the engine of the economy of the industrialized countries (García, Martínez \& Fernández (2010) and Galindo \& Méndez (2011)). Similarly, Álvarez, Giraldo \& Martínez (2014) point out that the sum of entrepreneurial projects contribute to social and economic development at local and national level; being the local area where the positive effects are more evident, which translate into an increase in the level of employment and the income of the population.

However, Lupiáñez, Priede \& Lopez-Cózar (2014) also emphasize the fact that among the empirical evidence there are no uniform results that allow a strong confirmation of this premise due to results vary depending on the context and the indicators used to quantify this relationship.

In addition, the premise that the lack of financial education has an impact on the development of young entrepreneurs (Singer, 2016) represents another area for further research on this subject, since it is difficult to conclude that lack of access to financing is one of the main constraints to innovation and the development of entrepreneurial projects (Lederman et al, 2014). 
Based on the above, the development of this project acquires relevance since, according to CONDUSEF (2013), there is a severe lag in our country in the area of financial education, which is evident since due to the lack of information people do not know the advantages or disadvantages they can get from their use.

Similarly, the National Entrepreneur Observatory (2013) emphasizes that in Mexico, despite the fact that entrepreneurs and MSMEs generate a significant amount of jobs and income for the country, they suffer from a series of weaknesses; among them, the difficulty to credit access, lack of knowledge on the subject and low productivity. Thus, raised these needs; we recognize the importance of continuing and contributing to the analysis with concrete proposals on these issues, since they represent areas of opportunity for economic growth and social development in our country.

In addition, these topics will remain strategic on the international agenda, as the World Bank (2015b) states that entrepreneurship and financial culture represent two of the major development tools. Added to this, in the context of the State of Veracruz, Mexico, there is little to no research regarding the level of financial education and entrepreneurial culture, jointly, among university students, which gives greater relevance to this work.

\section{Objectives}

The general objective of this study is to identify the level of entrepreneurial culture and financial education among university students of the different areas of knowledge of the Veracruzana University, Veracruz region. Also, two specific objectives are set: Detect the competencies of university students related to the areas of financial education and entrepreneurship and develop a series of proposals to meet the identified needs, as well as strengthen the strengths in these areas.

In this way, it is intended that this work represents an academic reference for the study of financial education and entrepreneurial culture, which in turn can be reproduced in the national and international context in public and private educational institutions, fulfilling one of the main goals among universities: the generation and dissemination of knowledge to generate social development.

\section{Literature review}

Some recent studies among entrepreneurial culture and financial education which are considered for the development of this study are shown in Table 1 :

\section{Table 1: Literature review}

\section{Author(s)}

Oseifuah, E. (2010).

Bae, T. et al (2014).

Njoroge, R. (2013).

Musie, L. (2015).

Lusimbo, E. (2016).

Abubakar, H. (2015).

Leifels, A. \& Metzger, G. (2015).

Ćumurović, A. \& Hyll, W. (2017).

Source: prepared by the author using documents cited above.

\section{Hypothesis}

After literature review, a set of hypothesis were stablished to contrast this study results with research in this field developed by authors mentioned in Table 1; these are:

\section{Main findings}

This study considers South African young entrepreneurs; financial literacy seems to contribute in developing better entrepreneurial capacities.

Results shown that there is a positive but weak correlation among entrepreneurial education and entrepreneurial intentions.

The study, focused in the Kenian context, reports a positive relationship between financial literacy and entrepreneurial skills.

There is a positive relationship between financial literacy levels shown by owners and small business performance; entrepreneurs with higher financial education levels reported greater business profits and higher labor demand.

Micro and small business owners with low financial literacy levels shown less efficient performance and lower profit growing rates.

Study shows that there is a strong relationship between financial literacy and small business performance in Africa; lack of credit access or market constrains represent some of main obstacles to promote entrepreneurship in that continent.

Focused on the German context, this study states that lower financial literacy drives to entrepreneuria potential reduction. Nevertheless, coaching and training programs contribute to reduce this problem.

Financial literacy is an effective mechanism for enhancing entrepreneurial activities. 
Hypothesis of work $(\mathrm{H} 0)$ : There is a low level of entrepreneurial culture and financial education among the students of the Veracruzana University, Veracruz region, which is reflected in the lack of knowledge of these concepts, as well as in their inability to make correct decisions associated with access and use of financial resources.

Null hypothesis $(\mathrm{H} 1)$ : There is a high level of entrepreneurial culture and financial education among students at the Veracruzana University, Veracruz region, which is reflected in the identification of these concepts, as well as their ability to make correct decisions associated with access and use of financial resources.

Alternative hypothesis $1(\mathrm{H} 2)$ : There is a high level of entrepreneurial culture and a low level of financial education among the students of the Veracruzana University, Veracruz region, which is reflected in the identification of concepts related to entrepreneurship, as well as in their inability to make correct decisions associated with access to and use of financial resources.

Alternative hypothesis $2(\mathrm{H} 3)$ : There is a low level of entrepreneurial culture and a high level of financial education among the students of the Veracruzana University, Veracruz region, which reflects their inability to identify concepts related to entrepreneurship, as well as in their ability to make correct decisions associated with access and use of financial resources.

Alternative Hypothesis $3(\mathrm{H} 4)$ : There is a high level of entrepreneurial culture and an average level of financial education among the students of the Veracruzana University, Veracruz region, which is reflected in a satisfactory level to identify concepts related to entrepreneurship as well as an intermediate capacity to make correct decisions associated with access and use of financial resources.

Alternative Hypothesis 4 (H5): There is an average level of entrepreneurial culture and a high level of financial education among the students of the Veracruzana University, Veracruz region, which is reflected in an average level to identify concepts related to entrepreneurship, as well as high ability to make correct decisions associated with access and use of financial resources.

\section{Methodology}

\section{Type of study}

This work is based on the development of an exploratory, non-experimental and cross-sectional research. This, since it is intended to identify the level of entrepreneurial culture and financial education among the population under study; In addition, this work is non-experimental since the variables involved in its development are not manipulated, and of a crosssectional type since the data will be collected in a single moment.

Regarding the characteristics of the information expected to be obtained and the techniques for its processing and subsequent interpretation, this study is considered to be of a quantitative and descriptive type.

\section{Study limitations}

As an exploratory and descriptive study, this research does not pretend to develop a comparative analysis among five Universidad Veracruzana Regions or other universities (public or private). Also, the characteristics of data do not provide enough information to perform deep statistical analysis. Nevertheless, these limitations are considered as opportunities for further studies which could enrich research in this area.

\section{Population and sample}

In terms of population, the universe is represented by the total number of students at the Veracruz University (UV) Veracruz region. In this sense, the latest online report issued by the Directorate of Institutional Planning of the UV for the 2015-2016 cycle, yields a total of 11,181 undergraduate students distributed in thirty educational programs.

To determine the sample size, we adopt the procedure indicated by Aguilar (2005), which uses the following formula:

$$
n=\frac{N Z^{2} P Q}{d^{2}(N-1)+Z^{2} P Q}
$$

Where: 
$\mathrm{N}=$ population 11,881

$\mathrm{n}=$ sample

$d=$ error allowed $(0.05)$

$Z=$ reliability level $(1.96)$

$p=$ probability of the event in favor $(0.5)$

$q=$ probability of the event against $(0.5)$

Once the formula was applied, a sample of 373 students was obtained; these were distributed based on the total enrollment for each of the thirty educational programs that make up the regional offer (check Annex 1). To round up sample size it was decided to increase the number of students up to 388. As inclusion criteria, only students with more than half of credit progress were considered, due to by that point they must have passed some courses which involved topics that promote financial education and entrepreneurial skills; new entry students were not surveyed as part of this research; open education system programs (which are given on an intensive basis during weekends) were not considered. Then, programs were grouped into five academic areas, which are shown in Table 2:

\section{Table 2: Programs by academic area}

$\begin{array}{lll}\text { Academic Area } & \text { Programs } & \text { Students (from total sample) } \\ \text { Administrative Economic } & 5 & 89 \\ \text { Health Sciences } & 8 & 94 \\ \text { Humanities } & 2 & 57 \\ \text { Technical } & 13 & 123 \\ \text { Biological Agropecuary } & 2 & 25 \\ \text { Total } & 30 & 388\end{array}$

Source: prepared by the author using data taken from Direction of Institutional Planning of Universidad Veracruzana, available at http://www.uv.mx/informacion-estadistica/files/2014/01/Series-Historicas-15_16.pdf

\section{Research instrument}

The field study lied on the application of a survey composed by 52 items divided in two sections; the first part of the instrument was designed to measure the level of entrepreneurial culture among students and items were based on Tiftik (2014) and Yılmaz \& Sünbül (2008), cited in Tiftik (2014); it is important to note that items considered from both cited studies were translated from the English to Spanish and some expressions had to be adapted to make them more appropriated for the Mexican context. The second part of the instrument was design to measure the financial education level and was constructed considering the work presented by Atkinson \& Messy (2012).

\section{Analysis of results}

Beginning with the analysis of the items focused on measuring the entrepreneurial culture among university students, most of them showed results at the high level, representing $54.12 \%$ of the total; if you add those located in the category "very high", the percentage increases to $65.46 \%$. On the other hand, it is important to note that $2.84 \%$ of the respondents were at a "low" level and $0.26 \%$ at a "very low" level. However, it is significant that $31.44 \%$ of the sample showed a "medium" level (Table 3).

Table 3: Entrepreneurial culture- total results

\begin{tabular}{|c|c|c|}
\hline \multicolumn{3}{|c|}{ Entrepreneurial culture } \\
\hline Level & Total & $\%$ \\
\hline Very High & 44 & $11.34 \%$ \\
\hline High & 210 & $54.12 \%$ \\
\hline Medium & 122 & $31.44 \%$ \\
\hline Low & 11 & $2.84 \%$ \\
\hline
\end{tabular}




\begin{tabular}{|l|l|l|} 
Very low & 1 & $0.26 \%$ \\
\hline Total & 388 & $100.00 \%$ \\
\hline
\end{tabular}

According to results shown in Table 3, it is relevant that only $3.1 \%$ of students were located on the lowest levels and most of them showed important elements that reflect an entrepreneurial profile. Also, if students are grouped into three categories (high, medium and low), evidence in favor of the good state of entrepreneurial culture are even more robust. This is represented in Chart 1.

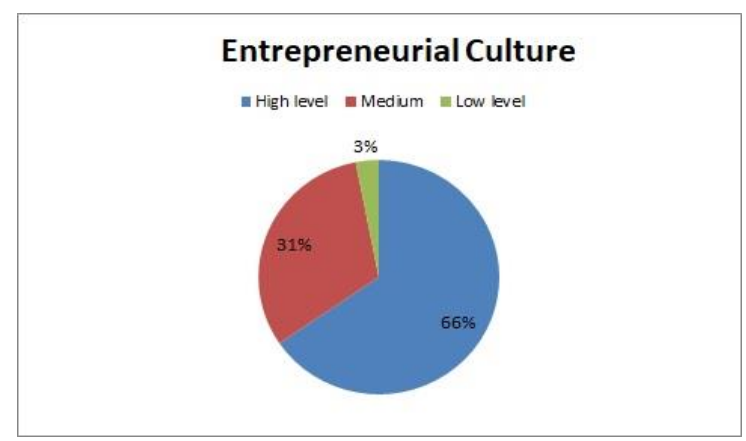

\section{Chart 1: Entrepreneurial culture}

In relation to the level of financial education, different findings were found, since $27.32 \%$ showed a "low" level and $5.15 \%$ "very low", representing $32.47 \%$ of the total; On the other hand, $47.43 \%$ were in the "medium" category, $18.81 \%$ in the "high" category and only $1.29 \%$ were "very high" (Table 4).

\section{Table 4: Financial education: total results}

\begin{tabular}{|l|l|l|}
\hline Financial education & Total & $\%$ \\
\hline Level & 5 & $1.29 \%$ \\
\hline Very High & 73 & $18.81 \%$ \\
\hline High & 184 & $47.42 \%$ \\
\hline Medium & 106 & $27.32 \%$ \\
\hline Low & 20 & $5.15 \%$ \\
\hline Very low & 388 & $100.00 \%$ \\
\hline Total & &
\end{tabular}

As done with entrepreneurial culture, results were grouped into three categories and it led us to a very different scenario among topics covered by the instrument; financial education clearly reported lower levels than those related to entrepreneurial culture, as shown in Chart 2. 


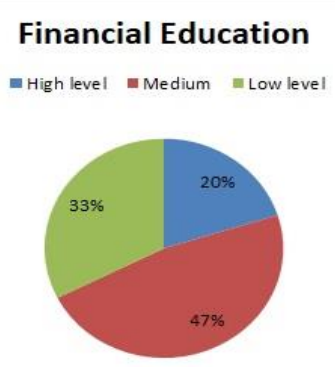

Chart 2. Financial education

It is important to note that just one student showed a "very low" level of entrepreneurial culture but when it came to financial education the sum in that category went up to twenty. Also, items in this topic were split into three areas: knowledge (items 1 to 9), behavior (items 10 to 15) and attitude (items 16 to 18); among these, behavior got the best scores (68\%), followed by knowledge (56\%) and attitude (45\%).Next, the Table 5 shows both aspects addressed in the instrument, so that they can be compared more easily.

\section{Table 5: Compared results among topics}

\begin{tabular}{|l|l|l|l|l|}
\hline Entrepreneurial culture & \multicolumn{2}{l|}{} & \multicolumn{2}{l|}{ Financial education } \\
\hline Level & TOTAL & $\%$ & TOTAL & $\%$ \\
\hline Very High & 44 & $11.34 \%$ & 5 & $1.29 \%$ \\
\hline High & 210 & $54.12 \%$ & 73 & $18.81 \%$ \\
\hline Medium & 122 & $31.44 \%$ & 184 & $47.42 \%$ \\
\hline Low & 11 & $2.84 \%$ & 106 & $27.32 \%$ \\
\hline Very Low & 1 & $0.26 \%$ & 20 & $5.15 \%$ \\
\hline Total & 388 & $100.00 \%$ & 388 & $100.00 \%$ \\
\hline
\end{tabular}

Based on Table 5, it can be stated that there is a medium-high trend in the levels of entrepreneurial culture, while it is medium-low in financial education; a deeper analysis from general descriptive statistics reported that entrepreneurial culture items had lower standard deviation compared to those focused on entrepreneurial culture which is congruent with these findings (check Annex 2). Next, Table 6 compares the results by academic area:

Table 6: Results by academic area

\begin{tabular}{|l|l|l|l|l|l|l|l|l|l|l|}
\hline \multirow{2}{*}{ Academic Area } & \multicolumn{3}{l}{\begin{tabular}{l}
\multicolumn{2}{l|}{ Administrative } \\
Economic
\end{tabular}} & \multicolumn{2}{l|}{ Technical } & \multicolumn{3}{l|}{ Health Sciences } & \multicolumn{2}{l|}{$\begin{array}{l}\text { Biological } \\
\text { Agropecuary }\end{array}$} \\
\hline Level & E.C. & F.E. & E.C. & F.E. & E.C. & F.E. & E.C. & F.E. & E.C. & F.E. \\
\hline Very High & $14.61 \%$ & $1.12 \%$ & $17.02 \%$ & $2.13 \%$ & $3.51 \%$ & $0.00 \%$ & $8.94 \%$ & $1.63 \%$ & $8.00 \%$ & $0.00 \%$ \\
\hline High & $55.06 \%$ & $14.61 \%$ & $54.26 \%$ & $10.64 \%$ & $59.65 \%$ & $14.04 \%$ & $49.59 \%$ & $26.02 \%$ & $60.00 \%$ & $40.00 \%$ \\
\hline Medium & $28.09 \%$ & $60.67 \%$ & $27.66 \%$ & $64.89 \%$ & $29.82 \%$ & $36.84 \%$ & $37.40 \%$ & $34.96 \%$ & $32.00 \%$ & $20.00 \%$ \\
\hline Low & $2.25 \%$ & $23.60 \%$ & $1.06 \%$ & $20.21 \%$ & $5.26 \%$ & $35.09 \%$ & $4.07 \%$ & $29.27 \%$ & $0.00 \%$ & $40.00 \%$ \\
\hline Very Low & $0.00 \%$ & $0.00 \%$ & $0.00 \%$ & $2.13 \%$ & $1.75 \%$ & $14.04 \%$ & $0.00 \%$ & $8.13 \%$ & $0.00 \%$ & $0.00 \%$ \\
\hline Total & $100 \%$ & $100 \%$ & $100 \%$ & $100 \%$ & $100 \%$ & $100 \%$ & $100 \%$ & $100 \%$ & $100 \%$ & $100 \%$ \\
\hline
\end{tabular}

Source: prepared by author. E.C.:Entrepreneurial Culture; F.E.: Financial Education.

Considering results provided in Table 6, it is clear that only the Biological Agropecuary academic area got students with both high entrepreneurial culture and financial education levels; nevertheless, also a high portion of surveyed obtained low 
financial education levels, so it is not possible to identify a really different scenario. Also, it is observed that students from Humanities area got the lowest scores in both dimensions.

As part from data analysis, a correlation test was performed and it was found that there is a positive but insignificant relationship between entrepreneurial culture and financial education levels among students; these results are provided in Table 7.

\section{Table 7: Correlation analysis}

\begin{tabular}{lll}
\hline & Financial education & Entrepreneurial culture \\
\hline Financial education & 1 & \\
Entrepreneurial culture & 0.12017762 & 1 \\
\hline
\end{tabular}

\section{Discussion of results}

After analyzing the data obtained from the application of the research instrument, it is observed that the results of this work resemble those presented by Bae et al (2014), considering the positive but weak relationship found among entrepreneurial skills and financial education levels shown by students; also, it could be said that this study sets the first steps to a path to identify if, in our context, financial education leads to higher financial education levels, which could let us to results similar to Njoroge (2013) and Musie (2015). If students surveyed in this research are followed after starting an entrepreneurial project, a further study could provide valuable information to validate the premises set by Lusimbo (2016) and Leifels \& Metzger (2015).

\section{Conclusion and recommendations}

Definitely, the relationship between variables selected for this study is one of the most important issues in the international agenda, considering the labor market hardness and scarcity of financial products for micro and smalls enterprises; in the context of Universidad Veracruzana, Veracruz Region, students shown a positive trend in terms of entrepreneurial skills, taking into consideration that more than half of them reported high or very high levels; though, when it came to financial education results were less optimistic due to more than half of subjects were located from medium to very low levels; in general terms, it can be said that students in this region present a high level of entrepreneurial skills and a medium level of financial education.

Then, it can be stated that both work hypothesis and null hypothesis are rejected and alternative hypothesis 3 is accepted. Future studies in this context could lead to identify which factors are enhancing entrepreneurial skills and limiting financial education among students from different areas, considering that a higher level of financial behavior was found among surveyed.

Based on the above, it is suggested that Universidad Veracruzana develop programs focused on materializing entrepreneurial potential into micro and small business, through coaching strategies and technical support to design robust business plans. Then, it will be highly recommended to follow these entrepreneurial projects to identify how these evolve through time, gaining valuable information that could help future entrepreneurs. Also, it is desirable to increase extracurricular activities like workshops or webinars aimed to disseminate the benefits of good practice in financial education.

Finally, it is important to mention that this research marks the path for a series of studies focused in explaining the relationship between entrepreneurial culture and financial skills in the context of Southern Mexico, helping researchers to define better strategies that could turn into public policies related to these topics.

\section{References}

[1] Abubakar, H. (2015). Entrepreneurship development and financial literacy in Africa. World Journal of Entrepreneurship, Management and Sustainable Development. Vol. 11 Issue 4, pp. 281-294. Available at http://www.emeraldinsight.com/doi/abs/10.1108/WJEMSD-04-2015-0020?journalCode=wjemsd

[2] Aguilar, S. (2005). Fórmulas para el cálculo de la muestra en investigaciones de salud. Salud en Tabasco, vol. 11, núm. 1-2, enero-agosto, pp. 333-338. Secretaría de Salud del Estado de Tabasco. Villahermosa, México. 
[3] Álvarez, A., Giraldo, O. \& Martínez, B. (2014). Emprendimiento, factor clave para el crecimiento económico. Algunos elementos de casos en Colombia y otros estudios. Escenarios: empresa y territorio, ND, 1-16.

[4] Atkinson, A. \& Messy, F. (2012). Measuring Financial Literacy: Results of the OECD / International Network on Financial Education (INFE) Pilot Study. OECD Working Papers on Finance, Insurance and Private Pensions..No..15,.OECD.Publishing,.Paris..http://dx.doi.org/10.1787/5k9csfs90fr4-en

[5] Bae, T., Qian, S. Miao, C. \& Fiet, J. (2014). The relationship between entrepreneurship education and entrepreneurial intentions: a meta-analytic review. Entrepreneurship, theory and practice. March 2014. Available at

https://www.researchgate.net/publication/260532516_The_Relationship_Between_Entrepreneurship_Educatio n_and_Entrepreneurial_Intentions_A_Meta-Analytic_Review

[6] BANAMEX \& UNAM. (2008). Primera Encuesta sobre Cultura Financiera en México. (1, 1-36), México, D.F.: Educación Financiera BANAMEX.

[7] BBVA. (2015). Una educación financiera y económica global ayuda a reducir la desigualdad de un país. 17 de febrero de 2016, de BBVA Available at: https://info.bbva.com/es/noticias/economia/consumo/una-educacionfinanciera-y-economica-global-ayuda-a-reducir-la-desigualdad-de-un-pais/

[8] Blasco, N. (2012). Educación financiera y espíritu emprendedor de los jóvenes en Aragón. Economistas, Colegio de Aragón. Universidad de Zaragoza. Available at http://ecoara.org/uploads/documentos/documentos_DOCUMENTO_SINTESIS_4c37629c.pdf

[9] Cai, J. (2015). El apoyo a las emprendedoras es una inversión clave para promover el desarrollo mundial. Voces, perspectivas para el desarrollo. Banco Mundial. Available at https://blogs.worldbank.org/voices/es/elapoyo-las-emprendedoras-es-una-inversion-clave-para-promover-el-desarrollo-mundial

[10] Carton, R., Hofer, C., \& Meeks, M. (1998). The entrepreneur and entrepreneurship: Operational definitions of their role in society. Annual International Council for Small Business Conference, Singapur.

[11] CONDUSEF. (2012). La educación financiera es para ti. 20 de febrero de 2016, de CONDUSEF. Available at: http://www.condusef.gob.mx/Revista/index.php/usuario-inteligente/277-la-educacion-financiera-es-para-ti

[12] CONDUSEF. (2013). Educación financiera, la clave. 20 de febrero de 2016, de CONDUSEF. Available at: http://www.condusef.gob.mx/Revista/PDF-s/2013/162/entrevistas.pdf

[13] CONDUSEF. (2015). Crédito joven: el apoyo para pasar de la idea a la acción. Available at: http://www.condusef.gob.mx/Revista/PDF-s/2015/182/inadem.pdf

[14] Ćumurović, A. \& Hyll, W. (2017). Financial literacy and self-employment. Global Financial Literacy Excellence Center. Available at http://gflec.org/wp-content/uploads/2017/04/CUMUROVIC-Paper-Cherry-Blossom2017.pdf?x28148

[15] Di Costanzo, M. (2013). Educación financiera, clave para supervivencia de Pymes. 20 de febrero de 2016, de Forbes México. Available at: http://www.forbes.com.mx/condusef-dara-impulso-a-mipymes-y-emprendedores/

[16] Galindo, M. \& Méndez, M.. (2011). Innovación y crecimiento económico: factores que estimulan la innovación. Cuadernos de gestión, 12, 51-58.

[17] García, C., Martínez, A. \& Fernández, R. (2010). Características del emprendedor influyentes en el proceso de creación empresarial y el éxito esperado. Revista Europea de Dirección y Economía de la Empresa, 19, 31-48.

[18] Inter-American Development Bank. (2014). BID y autoridades analizan políticas para impulsar el emprendimiento en la región. 21 de febrero de 2016, de Banco Interamericano de Desarrollo. Available at: http:/www.iadb.org/es/temas/competitividad-tecnologia-e-innovacion/bid-y-autoridades-analizan-politicaspara-impulsar-el-emprendimiento-en-la-region,18237.html

[19] Inter-American Development Bank. (2015). BID aprueba US\$300 millones para seguridad social y eficiencia del gasto en salud de República Dominicana. 20 de febrero de 2016, de BID. Available at: http://www.iadb.org/es/noticias/comunicados-de-prensa/2015-11-19/republica-dominicana-seguridad-social-ysalud,11327.html

[20] Kojo, E. (2010). Financial literacy and youth entrepreneurship in South Africa. African Journal of Economic and Management Studies, Vol. 1 Iss: 2, pp.164 - 182

[21] Lederman, D., Messina, J., Pienknagura, S. \& Rigolini, J. (2014). El Emprendimiento en América Latina: muchas empresas y poca innovación. Washington, Estados Unidos de América: Banco Mundial.

[22] Leifels, A. \& Metzger, G. (2015). Financial literacy helps with business start-ups: easier, better funded, more competitive. KFW Reseach. No. 107, 6th October. Available at https://www.kfw.de/PDF/Download- 
Center/Konzernthemen/Research/PDF-Dokumente-Fokus-Volkswirtschaft/Fokus-englische-Dateien/FokusNr.-107-Oktober-2015-Financial-literacy.pdf

[23] López, P. (2010). Educación financiera, cuestión de sentido común en las personas. 19 de febrero de 2016, de El Economista. Available at: Educación financiera, cuestión de sentido común en las personas

[24] Lupiáñez, L., Priede, T., \& López-Cózar, C. . (2014). El emprendimiento como motor del crecimiento económico. Boletín Económico de ICE, 3048, 55-63.

[25] Lusimbo, E. (2016). Relationship between financial literacy and growth of micro and small enterprises in Kenya: A case of Kakamenga Central sub-county. Jomo Kenyatta University of Agriculture and Technology. Available at http://ir.jkuat.ac.ke/bitstream/handle/123456789/2236/Lusimbo\%2C\%20Nekesa\%20\%20MSc.\%20\%20Entrepr enuership\%2C.\%202016..pdf?sequence=1\&isAllowed=y

[26] Marín, M. (2014). Educación financiera base del éxito de emprendedores. 18 de febrero de 2016, de El Economista. Available at: http://eleconomista.com.mx/sistema-financiero/2014/05/13/educacion-financierabase-exito-emprendedores

[27] Musie, L. (2015). The use of financial literacy concepts by entrepreneurs in the small and medium enterprise sector in Mpumalanga Provice, South Africa. Gordon Institute of Business Science. University of Pretoria. Available https://repository.up.ac.za/bitstream/handle/2263/52268/Musie_Use_2016.pdf?sequence=1\&isAllowed=y

[28] National Entrepreneur Observatory. (2013). Análisis transversal del gasto en políticas de apoyo a los emprendedores, MiPYMES. 20 de febrero de 2016, de Instituto Nacional del Emprendedor. Available at: http://www.mx.undp.org/content/dam/mexico/docs/Publicaciones/PublicacionesReduccionPobreza/one/Analisi stransversaldelgastoenpoliticasdeapoyoaemprendedoresyMiPyMEs.pdf

[29] Neck, H.. (2014). La educación es importante para iniciar un negocio: Heidi Neck. 18 de febrero de 2016, de Innovación UNAM. Available at: http://www.innovacion.unam.mx/entrevista_3.html

[30] Njoroge, R. (2013). Relationship between financial literacy and entrepreneurial success in Nairobi County Kenia. Available at http://chss.uonbi.ac.ke/sites/default/files/chss/NJOROGE\%20ROBERT-D61-75875-2012.pdf

[31] OECD. (2010). Multilingual Summaries. The OECD Innovation Strategy: Getting a head start on tomorrow. Available at: $h$ ttps://www.oecd.org/sti/45302715.pdf

[32] Oseifuah, E. (2010). Financial Literacy and youth entrepreneurship in South Africa. African Journal of Economic and Management Studies, Vol. 1 Issue 2, pp. 164-182. Available at http://www.emeraldinsight.com/doi/abs/10.1108/20400701011073473

[33] Singer, S. (2016). Falta educación financiera para el desarrollo de jóvenes emprendedores. 21 de febrero de 2016, de El Financiero-Bloomberg. Available at: http://www.elfinanciero.com.mx/tv/falta-educacion-financierapara-el-desarrollo-de-jovenes-emprendedores-singer.html

[34] Smyth, M. (2011). Educación financiera para todos: estrategias y buenas prácticas de educación financiera en la Unión Europea. 19 de febrero de 2016, de Comité Económico y Social Europeo. Available at: http://www.eesc.europa.eu/resources/docs/qe-30-12-894-es.pdf

[35] Tiftik, H. (2014). A Survey of Entrepreneurial Tendencies Candidate Young Entrepreneurs: Foundation University Sample. Journal of Management Research. Vol. 6, No. 2. ISSN 1941-899X

[36] World Bank. (2013). Ser emprendedor en México, ¿misión imposible? 19 septiembre 2013. Available at http://www.bancomundial.org/es/news/feature/2013/09/19/entrepreneurship-innovation-mexico

[37] World Bank. (2015a). Los jóvenes emprendedores que miran más allá del dinero. 13 abril 2015. Available at http://www.bancomundial.org/es/news/feature/2015/04/13/los-jovenes-emprendedores-que-miran-mas-alladel-dinero

[38] World Bank. (2015b). Los empresarios jóvenes, como factores que impulsan el crecimiento sostenible. 20 de febrero de 2016, de Banco Mundial. Available at: http://envivo.bancomundial.org/empresarios-jovenes-factoresque-impulsan-el-crecimiento-sostenible

[39] Yılmaz, E. \& Sünbuil, A. (2008). Üniversite Öğrencilerine Yönelik Girişimcilik Ölçeğinin Geliştirilmesi. Selcuk University Social Sciences Institute Journal, 21.

\section{Annex 1: Distribution of the sample through educational programs}

\begin{tabular}{|l|l|l|l|l|}
\hline Program & Enrolled & Percentage of total & Sample & Final sample \\
\hline
\end{tabular}




\begin{tabular}{|l|l|l|l|l|}
\hline International Agribusiness & 112 & $0.94 \%$ & 3.52 & 4 \\
\hline Veterinary Medicine & 651 & $5.48 \%$ & 20.44 & 21 \\
\hline Dentist & 621 & $5.23 \%$ & 19.50 & 20 \\
\hline Physical Education & 434 & $3.65 \%$ & 13.63 & 14 \\
\hline Nursing & 590 & $4.97 \%$ & 18.52 & 19 \\
\hline Medicine & 931 & $7.84 \%$ & 29.23 & 30 \\
\hline Chiropractic & 68 & $0.57 \%$ & 2.13 & 3 \\
\hline Nutrition & 529 & $4.45 \%$ & 16.61 & 17 \\
\hline Psychology & 446 & $3.75 \%$ & 14.00 & 15 \\
\hline Bioanalysis & 628 & $5.29 \%$ & 19.72 & 20 \\
\hline Management & 867 & $7.30 \%$ & 27.22 & 28 \\
\hline Tourist Management & 451 & $3.80 \%$ & 14.16 & 15 \\
\hline Computer Systems Management & 332 & $2.79 \%$ & 10.42 & 11 \\
\hline Accountancy & 818 & $6.88 \%$ & 25.68 & 26 \\
\hline Administration and Business Management & 277 & $2.33 \%$ & 8.70 & 9 \\
\hline Communication Sciences & 631 & $5.31 \%$ & 19.81 & 20 \\
\hline Pedagogy & 683 & $5.75 \%$ & 21.44 & 22 \\
\hline Architecture & 45 & $0.38 \%$ & 1.41 & 2 \\
\hline Chemical Engineering & 313 & $2.63 \%$ & 9.83 & 10 \\
\hline Civil Engineering & 728 & $6.13 \%$ & 22.86 & 23 \\
\hline Topographical Engineering & 108 & $0.91 \%$ & 3.39 & 4 \\
\hline Engineering in Electronics and Communications & 274 & $2.31 \%$ & 8.60 & 9 \\
\hline Electrical Mechanical Engineering & 29 & $0.24 \%$ & 0.91 & 1 \\
\hline Naval Engineering & 204 & $1.72 \%$ & 6.40 & 7 \\
\hline Metallurgical Engineering of Materials & 119 & $1.00 \%$ & 3.74 & 4 \\
\hline Industrial Engineering & 164 & $1.38 \%$ & 5.15 & 6 \\
\hline Electrical Engineering & 232 & $1.95 \%$ & 7.28 & 8 \\
\hline Mechanical Engineering & 284 & $2.39 \%$ & 8.92 & 9 \\
\hline Informatics Engineering & 152 & $1.28 \%$ & 4.77 & 5 \\
\hline Mechatronics Engineering & 160 & $1.35 \%$ & 5.02 & 6 \\
\hline Total & 11881 & $100.00 \%$ & 373 & 388 \\
\hline Soure: prepard by the & & \\
\hline
\end{tabular}

Source: prepared by the author using data taken from Direction of Institutional Planning of Universidad Veracruzana, available at http://www.uv.mx/informacion-estadistica/files/2014/01/Series-Historicas-15_16.pdf

\section{Annex 2: Descriptive statistics}

\begin{tabular}{llll}
\hline Financial education & & Entrepreneurial culture & 3.73453608 \\
Mean & 2.83762887 & Mean & 0.03572656 \\
Typical Error & 0.04230771 & Typical Error & 4 \\
Median & 3 & Median & 4 \\
Mode & 3 & Mode & 0.70373169 \\
Standard deviation & 0.8333653 & Standard deviation & 0.49523829 \\
Sample variance & 0.69449772 & Sample variance & 0.23889786 \\
Kurtosis & -0.1779926 & Kurtosis & -0.2467376 \\
Skewness coefficient & -0.0916273 & Skewness coefficient & 4 \\
Range & 4 & Range & 1 \\
Minimum & 1 & Minimum & 5 \\
Maximum & 5 & Maximum & 1449 \\
Sum & 1101 & Sum &
\end{tabular}


